\title{
Implementasi Nilai Kewirausahaan Jenjang Sekolah Dasar Pada Sekolah Mitra STKIP Muhammadiyah Bangka Belitung di Kecamatan Gabek Kota Pangkalpinang
}

\author{
Diana Pramesti, Adevia Indah Kusuma \\ STKIP Muhammadiyah Bangka Belitung, Indonesia \\ diana.pramesti@stkipmbb.ac.id, adevia.indahkusuma@stkipmbb.ac.id
}

\begin{abstract}
Abstrak: Penelitian ini merupakan penelitian deskriptif kualitatif. Tujuan penelitian ini untuk mengetahui implementasi nilai kewirausahaan jenjang sekolah dasar. Subjek penelitian adalah sekolah mitra STKIP Muhammadiyah Bangka Belitung yang berjumlah 5 sekolah dasar di kecamatan Gabek, Pangkalpinang. Setiap sekolah diambil 9 orang responden terdiri atas 5 orang siswa, 1 Kepala Sekolah, 1 guru kelas, 1 pembina ekstrakurikuler dan 1 orang bagian kurikulum. Teknik analisis datanya menggunakan langkah reduksi data, display data dan menarik kesimpulan/verifikasi. Hasil penelitian menunjukkan bahwa implementasi nilai mandiri, nilai berani mengambil resiko dan nilai kreatif dengan skor tertinggi berturut $74,17 \%, 74,56 \%$ dan $85 \%$ pada SD Negeri 10 . Skor tertinggi untuk nilai kerja keras terlihat pada SD Negeri 6, dan skor berorientasi tindakan tertinggi $84,16 \%$ pada SD Negeri 62 . Nilai kepemimpinan tertinggi dengan skor $80,83 \%$ pada SD Negeri 22. Kesimpulannya adalah nilai-nilai kewirausahaan telah terimplementasi secara baik di beberapa sekolah meskipun belum membuat program terkait penanaman nilai kewirausahaan secara khusus.
\end{abstract}

Kata kunci: Implementasi Nilai, Kewirausahaan, Sekolah Dasar

\section{Implementation of Entrepreneurship Values at Elementary School Levels in STKIP Muhammadiyah Bangka Belitung Partner Schools in Gabek District, Pangkalpinang City}

\begin{abstract}
This research is a qualitative descriptive study. The purpose of this study was to determine the implementation of entrepreneurship values at the elementary school level. The subjects of the study were the partner schools of STKIP Muhammadiyah Bangka Belitung, amounting to 5 elementary schools in Gabek sub-district, Pangkalpinang. Each school was taken nine respondents consisting of 5 students, 1 School Principal, 1 class teacher, one extracurricular coach and one curriculum section person. The data analysis technique uses the steps of data reduction; data display and concluding / verification. The results showed that the implementation of the independent value, the value of risk-taking and artistic value with the highest scores respectively $74.17 \%, 74.56 \%$ and $85 \%$ in the 10 th Elementary School. The highest score for the hard work value was seen in the 6 th Elementary School and the score action-oriented highest $84.16 \%$ in the 62 nd Elementary School. The highest leadership value with a score of $80.83 \%$ in 22th Elementary School. The conclusion is that entrepreneurial values have been implemented well in several schools, even though they have not made programs related to the inculcation of entrepreneurial values specifically.
\end{abstract}

Keywords: Value Implementation, Entrepreneurship, Elementary School

\section{PENDAHULUAN}

Pendidikan karakter di jenjang tingkat Sekolah Dasar (SD) memiliki peranan yang sangat penting untuk diterapkan di sekolah. Karakter yang ditanamkan sedini mungkin di sekolah ini akan sangat Umumnya, pendidikan karakter pada proses pembelajaran sekolah dikenal dengan 18 nilai karakter yang meliputi nilai religius, jujur, toleransi, disiplin, kerja keras, kreatif, mandiri, demokratis, ingin tahu, semangat kebangsaan, cinta tanah air, menghargai prestasi, bersahabat, 
cinta damai, gemar membaca, peduli lingkungan, peduli sosial, dan tanggung jawab. Pendidikan kewirausahaan secara khusus terdiri dari 17 nilai pendidikan kewirausahaan (Husaini \& Dkk, 2010). Nilai-nilai tersebut yaitu berani mengambil resiko, berorientasi pada tindakan, kepemimpinan, inovatif, kerja sama, pantang menyerah, komitmen, realistis, komunikatif, dan motivasi kuat untuk sukses. Di antara 17 nilai kewirausahaan tersebut terdapat 6 nilai kewirausahaan dasar (mandiri, kreatif, kerja keras, berorientasi pada tindakan, berani mengambil resiko, kepemimpinan) yang menjadi standar pencapaian pembelajaran di sekolah pada tiap jenjangnya. Perbedaan yang terdapat pada ke-6 nilai kewirausahaan ini dengan 18 nilai karakter adalah pada indikator pencapaiannya dan terdapat beberapa nilai kewirausahaan dasar yang tidak ada pada 18 nilai karakter seperti berani mengambil resiko dan berorientasi pada tindakan.

Karakter yang dimiliki seorang wirausaha saat ini dipercaya sebagai salah satu solusi bagi bangsa Indonesia khususnya untuk menciptakan sumber daya manusia yang memiliki sikap wirausaha yang tidak hanya memperkenalkan peserta didik kepada dunia usaha tetapi dapat mengadopsi nilai karakter kewirausahaan itu sendiri pada kehidupannya. Nilai karakter kewirausahaan yang dapat ditumbuhkembangkan di lembaga formal adalah melalui nilai pendidikan kewirausahaan yang diimplementasikan pada tingkat sekolah dasar (SD) sebanyak 6 nilai tersebut.

Pendidikan karakter dan kewirausahaan merupakan bekal penting yang harus dimiliki oleh setiap generasi muda penerus bangsa. Hal ini bertujuan untuk menghasilkan Sumber Daya Manusia (SDM) yang berkualitas dan mampu bertahan dari berbagai tantangan global (Dewi et al., 2015). Pendidikan kewirausahaan merupakan salah satu bidang pendidikan dengan menitikberatkan pada pembentukan karakter manusia (Siwiyanti \& Uswatun, 2016), khususnya pendidikan karakter di SD dengan membangun karakter berdasarkan prinsip-prinsip pendidikan, nilai-nilai kehidupan yang berlandaskan dengan pengembangan budi pekerti luhur menjadi core value dalam pendidikan karakter (Akbar et al., 2014). Menumbuhkan jiwa kewirausahaan yang dilakukan dengan menyisipkan kurikulum dasar kewirausahaan di setiap mata pelajaran yang ditekuni. Pendidikan karakter dan kewirausahaan yang diimplementasikan di SD bertujuan juga untuk mengembangkan sikap positif dan mendapatkan pengetahuan dasar tentang menumbuhkan nilai-nilai kewirausahaan di masa depan (Heilbrunn, 2010).

Ditinjau dari penjelasan tersebut, maka pentingnya penanaman nilai kewirausahaan diimplementasikan di SD adalah untuk menstimulasi siswa memiliki pola pikir seperti pengusaha yang dimulai sejak dini. Penelitian oleh Deveci \& Leino (Deveci \& Seikkula-Leino, 2018) mengenai pentingnya kurikulum kewirausahaan dalam bidang pendidikan adalah untuk mampu bertahan dan mampu menghadapi tantangan global dari sektor ekonomi di masa depan, yang dapat ditanamkan melalui mata pelajaran di kurikulum pendidikan. Kemendiknas (Husaini \& Dkk, 2010) kewirausahaan adalah nilai-nilai yang membentuk karakter dan perilaku seseorang yang selalu kreatif berdaya, bercipta, berkarya, dan bersahaja serta berusaha dalam rangka 
meningkatkan pendapatan dalam usahanya. Sehingga, perlunya dilakukan pembentukan dan penanaman nilai kewirausahaan di tingkat SD melalui proses pembelajaran. Upaya ini dilakukan karena tujuan akhir dari pencapaian nilai kewirausahaan akan bermanfaat di kemudian hari, baik bagi peserta didik, sekolah maupun lingkungan masyarakat. Menurut Usman, dkk (Husaini \& Dkk, 2010) siswa lulusan jenjang SD diharapkan memiliki 6 nilai pokok kewirausahan yang tercermin pada karakternya yang diintegrasikan di dalam proses pembelajaran. Proses pengintegrasian nilai pendidikan kewirausahaan ini, dibutuhkan berbagai bentuk usaha dalam menerapkannya. Indikator ketercapaian implementasi nilai kewirausahaan dapat dilihat dari tiga komponen yang meliputi siswa sebagai individu, proses pembelajaran di kelas serta lingkungan sekolah.

Dengan demikian disadari bahwa pencapaian implementasi nilai kewirausahaan ini juga membutuhkan suatu kajian agar sekolah mampu mengetahui secara terstruktur mengetahui bagaimana profil mereka dalam usaha pemenuhan standar. Sehingga dapat menjadi bahan bagi sekolah untuk merencanakan strategi penerapan yang lebih baik ke depannya. Menurut Usman,dkk (Husaini \& Dkk, 2010), prinsip yang digunakan dalam pengembangan pendidikan kewirausahaan adalah proses pengembangan nilai-nilai kewirausahaan merupakan proses panjang dan berkelanjutan yang dimulai sejak awal peserta didik masuk sampai selesai dari suatu satuan pendidikan; materi nilai kewirausahaan diintegrasikan ke dalam setiap mata pelajaran dapat melalui materi, metode, maupun penilaian; pada pelaksanaan pembelajaran di kelas, guru tidak perlu mengubah pokok bahasan tetapi menggunakan materi pokok bahasan itu untuk mengembangkan nilai kewirausahaan; perlunya penggunaan metode pembelajaran yang aktif dan menyenangkan.

Rahasia kewirausahaan terletak pada kreativitas dan keinovasian (Suryana, 2014). Kreativitas adalah kemampuan mengembangkan ide dan cara-cara baru dalam memecahkan masalah dan menemukan peluang. Sementara itu, inovasi adalah kemampuan menerapkan kreativitas dalam rangka memecahkan masalah dan menemukan peluang. Seorang wirausahawan harus mampu menciptakan sesuatu yang baru dan berbeda atau sesuatu yang sudah ada tetapi dibuat dengan cara yang berbeda. Dengan demikian, esensi dari kewirausahaan adalah menciptakan nilai tambah di pasar melalui proses kombinasi antara sumber daya dengan cara-cara baru dan berbeda agar mampu bersaing.

Nilai-nilai kewirausahaan yang ditumbuhkembangkan dan diimplementasikan dalam pendidikan kewirausahaan dijenjang SD dalam penelitian ini terdiri atas enam nilai yaitu mandiri, kreatif, berani mengambil resiko, berorientasi pada tindakan, kepemimpinan, dan kerja keras. Sedangkan nilai lainnya dapat diinternalisasikan secara mandiri sesuai dengan kebutuhan sekolah. 


\section{METODE}

Penelitian ini menggunakan penelitian deskriptif kualitatif menggambarkan dan menjelaskan tentang implementasi nilai-nilai kewirausahaan jenjang SD yang menjadi mitra STKIP Muhammadiyah Bangka Belitung.

Populasi dalam penelitian ini adalah semua SD mitra STKIP Muhammadiyah Bangka Belitung tahun 2019 di wilayah Pangkalpinang yang berjumlah 34 Sekolah Dasar. Sampel dalam penelitian ini menggunakan teknik purposive sampling yang merupakan salah satu teknik sampling non random sampling, dengan cara kerja peneliti menentukan pengambilan sampel dengan cara menetapkan ciri-ciri khusus sesuai dengan tujuan penelitian sehingga diharapkan dapat menjawab permasalahan penelitian. Hasil yang diperoleh dapat memecahkan masalah serta memberikan nilai yang lebih representatif, sehingga teknik yang diambil dapat memenuhi objektif dilakukannya suatu penelitian yang didasarkan pada pertimbangan SD mitra yang berada dalam satu wilayah kecamatan dan berstatus negeri serta memiliki jumlah SD mitra paling banyak di kecamatannya. Selain itu, sekolah mitra pada 1 kecamatan ini direncanakan sebagai percontohan ke depannya. Pada tabel di atas terlihat bahwa kecamatan yang memiliki SD Negeri terbanyak yaitu berada di wilayah kecamatan Gabek Kota Pangkalpinang dengan jumlah sekolah sebanyak 6 buah. Teknik analisis data yang digunakan terdiri atas beberapa langkah. Diawali dengan analisis data kualitatif yang meliputi reduksi data, display data dan kesimpulan/verifikasi.

\section{HASIL DAN PEMBAHASAN}

Hasil dari implementasi nilai-nilai kewirausahaan dapat dilihat pada olahan data primer yang didapatkan melalui proses mengolah hasil kuesioner yang disebar dan wawancara serta dokumentasi tertulis maupun lapangan. Penetapan skor diperoleh dari membandingkan antara indikator-indikator dari nilai kewirausahaan dasar yang telah dibuatkan kriteria penilaiannya dengan hasil observasi, wawancara serta kelengkapan dokumentasinya. Hasil penelitian menunjukkan bahwa implementasi nilai mandiri, nilai berani mengambil resiko dan nilai kreatif dengan pengkategorian kriteria dari Widoyoko (Widoyoko, 2009) diperoleh skor tertinggi berturut $74,17 \%, 74,56 \%$ dan $85 \%$ pada SD Negeri 10 . Skor tertinggi untuk nilai kerja keras terlihat pada SD Negeri 6, dan skor berorientasi tindakan tertinggi 84,16\% pada SD Negeri 62 . Nilai kepemimpinan tertinggi dengan skor $80,83 \%$ pada SD Negeri 22. Skor lengkap pada kegiatan ini dapat dilihat pada tabel berikut ini:

Tabel 1. Implementasi Nilai-Nilai Kewirausahaan

*dalam persentase

\begin{tabular}{|c|c|c|c|c|c|c|c|c|c|c|c|c|}
\hline \multirow{2}{*}{$\begin{array}{c}\text { Nilai } \\
\text { Sekolah }\end{array}$} & \multicolumn{2}{|c|}{ Mandiri } & \multicolumn{2}{|c|}{$\begin{array}{c}\text { Berani Mengambil } \\
\text { Resiko }\end{array}$} & \multicolumn{2}{|c|}{ Kerja Keras } & \multicolumn{2}{|c|}{$\begin{array}{c}\text { Berorientasi pada } \\
\text { Tindakan }\end{array}$} & \multicolumn{2}{|c|}{ Kepemimpinan } & \multicolumn{2}{|c|}{ Kreatif } \\
\hline & Skor & Kategori & Skor & Kategori & Skor & Kategori & Skor & Kategori & Skor & Kategori & Skor & Kategori \\
\hline SD N 62 & 65 & Baik & 70,83 & Baik & 65,28 & Baik & 72,22 & Baik & 72,08 & Baik & 81,66 & Sangat \\
\hline
\end{tabular}




\begin{tabular}{|c|c|c|c|c|c|c|c|c|c|c|c|c|}
\hline & & & & & & & & & & & & Baik \\
\hline SD N 22 & 43,73 & Cukup & 65 & Baik & 48,33 & Cukup & 69,44 & Baik & 80,83 & $\begin{array}{c}\text { Sangat } \\
\text { Baik }\end{array}$ & 80,83 & $\begin{array}{c}\text { Sangat } \\
\text { Baik }\end{array}$ \\
\hline SD N 23 & 55,83 & Cukup & 60,42 & Baik & 61,11 & Baik & 74,78 & Baik & 75,83 & Baik & 79 & Baik \\
\hline SD N 10 & 74,17 & Baik & 74,56 & Baik & 59,17 & Cukup & 77,55 & Baik & 78,33 & Baik & 85 & $\begin{array}{c}\text { Sangat } \\
\text { Baik }\end{array}$ \\
\hline SD N 62 & 56,6 & Cukup & 67,08 & Baik & 64,72 & Baik & 84,16 & $\begin{array}{c}\text { Sangat } \\
\text { Baik }\end{array}$ & 78,33 & Baik & 74,17 & Baik \\
\hline
\end{tabular}

Persen keterlaksanaan selanjutnya dideskripsikan dan secara mendalam dijabarkan melalui hal-hal yang mendukung hasil tersebut. Deskripsi berpedoman pada pengkategorian kriteria dari Widoyoko (2009: 242) yang dapat dilihat pada tabel di bawah ini:

Tabel 2. Kategori Kriteria Implementasi Nilai Kewirausahaan

\begin{tabular}{cc}
\hline Persentase (\%) & Kategori \\
\hline $80-100$ & Sangat Baik \\
$60-79,99$ & Baik \\
$40-59,99$ & Cukup \\
$20-39,99$ & Kurang \\
$0-19,99$ & Sangat Kurang \\
\hline
\end{tabular}

Berdasarkan tabel di atas diketahui bahwa nilai mandiri yang paling terlihat terdapat di SD Negeri 10 Pangkalpinang dengan skor 74,17\% dengan kategori baik. Hasil penelitian ini didukung dari hasil penelitian lain yang mengukur nilai kemandirian siswa dan diperoleh hasil bahwa terjadi peningkatan nilai kemandirian sebesar 19,2\% dengan kategori tinggi (Rizki, 2010), yang didukung oleh beberapa kegiatan yang menstimulasi terjadinya peningkaan kemandirian pada siswa melalui kegiatan internalisasi kewirausahaan melalui ekstrakurikuler (Sabiki, 2018). Nilai mandiri berada pada kategori baik karena pihak sekolah terus berupaya menumbuhkembangkan kemandirian peserta didik di antaranya melalui budidaya hidroponik dan greenhouse yang menuntut peserta didik untuk bertanggung jawab dengan proyek tersebut dan tidak bergantung kepada guru. Peserta didik dibebaskan dalam mencari sumber bacaan selama proses kegiatan pembelajaran, sehingga peserta didik bebas bereksplorasi terhadap sumber bacaan yang digunakan dan memupuk nilai kemandirian. Semakin banyak sumber bacaan yang digunakan, maka ilmu pengetahuan yang diperoleh juga semakin banyak.

Nilai berani mengambil resiko paling tampak kuat terdapat di SD Negeri 10 Pangkalpinang dengan skor $74,56 \%$ dengan kategori baik. Hal ini didukung oleh adanya prestasi yang sering diperoleh oleh SD Negeri 10 Pangkalpinang dari berbagai kejuaraan yang diperoleh baik di tingkat kabupaten maupun di tingkat provinsi. Nilai kerja keras paling terlihat terdapat di SD Negeri 6 Pangkalpinang dengan skor $65,28 \%$ dan masuk pada kategori baik. Hal ini didukung oleh adanya pojok baca yang ada di setiap sudut kelas. Pihak sekolah juga menyediakan sarana dan prasarana 
yang menunjang peserta didik mencari sumber bacaan sehingga minat baca peserta didik dapat ditingkatkan.

Nilai Berorientasi pada tindakan yang telihat menonjol terdapat di SD Negeri 62 Pangkalpinang dengan skor $84,16 \%$ dan masuk kategori sangat baik. Hal ini didukung oleh adanya layanan prima yang diberikan oleh pihak sekolah untuk mengembangkan gagasannya khususnya di bidang seni. Peserta didik diberikan ruang dan fasilitas yang seluas-luasnya untuk mengembangkan potensi seni yang dimilikinya sehingga sekolah ini memiliki prestasi di bidang kesenian khususnya seni tari yang bagus yang dibuktikan dengan berbagai kejuaraan yang diperolehnya. Selain itu, pihak sekolah juga selalu terbuka akan masukan-masukan yang diberikan oleh guru maupun orang tua peserta didik terkait dengan program-program sekolah.

Nilai kepemimpinan yang tampak paling kuat telihat di SD Negeri 22 Pangkalpinang dengan skor $80,83 \%$ dan masuk kategori sangat baik. Hal ini dikarenakan guru selalu berupaya membangun suasana diskusi kelas melalui tanya jawab sebelum pembelajaran dimulai. Mekanisme pembentukan ketua kelas melalui voting sehingga menumbuhkan sikap demokratis peserta didik. Nilai kreatif yang paling terlihat pada SD Negeri 10 Pangkalpinang dengan skor 85\% msduk kategori sangat baik. Hal ini dapat dilihat dari banyaknya hasil karya siswa yang dipajang di sekitar lingkungan sekolah terutama yang terbuat dari barang bekas.

Hasil penelitian ini dapat menjadi bahan dasar bagi sekolah untuk menetapkan strategi yang dibutuhkan selanjutnya bagi manajemen SD dalam menumbuhkan jiwa kewirauusahaan di kemudian hari. Menurut Kusuma (Kusuma, 2017) strategi manajemen SD di sekolah dapat dilakukan melalui beberapa kegiatan. Kegiatan-kegiatan tersebut meliputi kegiatan market week, kegiatan field trip pasar tradisional dan pasar modern, ekskul berbasis kewirausahaan, penataan suasana sekolah untuk penanaman nilai-nilai kewirausahaan, pelatihan berbasis kewirausahaan yang berkesinambungan bagi tenaga pendidik dan pemberian penghargaan.

\section{SIMPULAN}

Dari hasil tersebut, dapat disimpulkan bahwa nilai-nilai kewirausahaan saat ini belum sepenuhnya terimplementasikan baik di dalam kegiatan pembelajaran maupun di luar pembelajaran, namun memiliki potensi untuk diterapkan dengan sangat baik, serta memenuhi semua indikator dari nilai kewirausahaan itu sendiri. Lingkungan sekolah pun masih belum sepenuhnya mendukung. pemahaman akan implementasi nilai-nilai kewirausaahaan. Pola pikir mengenai kewirausahaan masih identik dengan siswa berjualan. Kepala sekolah dan guru mengaku bahwa mereka masih merasa kebingungan bagaimana cara mengimplementasikan nilai kewirausahaan di dalam kegiatan akademik siswa secara menyeluruh. Masih diperlukan adanya sosialisasi maupun pendampingan dalam upaya meningkatkan pemahaman guru, kepala sekolah, bagian kurikulum, pembina ektrakurikuler dan warga sekolah lain akan pentingnya implementasi nilai-nilai kewirausahaan yang terintegrasi baik di dalam perangkat pembelajaran, proses kegiatan belajar 
mengajar, maupun di lingkungan sekolah. Belum adanya kebijakan sekolah yang berkaitan dengan penumbuhan nilai kewirausahaan secara khusus sehingga proses implementasi nilai kewirausahaan tidak bisa berjalan secara maksimal karena selama ini implementasi nilai-nilai kewirausahaan hanya sebatas di ekstrakurikuler.

Saran dari penelitian ini adalah nilai-nilai kewirausahaan yang telah terimplementasi perlu pengembangan lebih lanjut agar dapat menjadi contoh bagi sekolah-sekolah lainnya dan perlu adanya pembinaan khusus terkait dengan cara mengimplementasikan nilai-nilai kewirausahaan di jenjang sekolah dasar sehingga dapat berjalan dengan lebih baik dan terarah.

\section{DAFTAR PUSTAKA}

Akbar, S., Samawi, A., Arafiq, M., \& Hidayah, L. (2014). Model Pendidikan Karakter yang Baik di SD (Studi Lintas Situs Best Practices). Jurnal Sekolah Dasar Kajian Teori Dan Praktik Pendidikan, 2(2), 139-151.

Deveci, I., \& Seikkula-Leino, J. (2018). A review of entrepreneurship education in teacher education. Malaysian Journal of Learning and Instruction, 15(1), 105-148. https://doi.org/10.32890/mjli2018.15.1.5

Dewi, L., Yani, A., \& Suhardini, A. D. (2015). Model Pendidikan Karakter dan Kewirausahaan Berbasis Etnopedagogis di Sekolah Dasar Kampung Cikondang. MIMBAR, Jurnal Sosial Dan Pembangunan, 31(2), 399. https://doi.org/10.29313/mimbar.v31i2.1480

Heilbrunn, S. (2010). Advancing Entrepreneurship in An Elementary School: A Case Study. International Education Studies, 3(2). https://doi.org/10.5539/ies.v3n2p174

Husaini, U., \& Dkk. (2010). Bahan Pelatihan Pengembangan Pendidikan Kewirausahaan. Kementrian Pendidikan Nasional Badan Penelitian dan Pengembangan Pusat Kurikulum.

Kusuma, A. I. (2017). Strategi Manajemen Sekolah Dasar Dalam Menumbuhkan Jiwa Kewirausahaan. Jurnal JPSD (Jurnal Pendidikan Sekolah Dasar), 4(1), 77. https://doi.org/10.26555/jpsd.v4i1.a9590

Rizki, A. A. (2010). Penanaman Nilai-Nilai Kewirausahaan dalam Lingkungan Keluarga pada Siswa Kelas XII Konsentrasi Jasa Boga di SMK Negeri 1 Sewon. Universitas Negeri Yogyakarta.

Sabiki, A. (2018). Pendidikan Kewirausahaan pada Siswa Sekolah Dasar Islam Terpadu Smart Cendekia Karanganom Kabupaten Klaten Tahun 2018. IAIN Yogyakarta.

Siwiyanti, L., \& Uswatun, D. A. (2016). Mengembangkan Pendidikan Kewirausahaan Melalui 
Jurnal Ekonomi \& Pendidikan, 17(1), 2020

Pembelajaran IPA Di SD. Pedagogik, IV(2), 58-70.

Suryana. (2014). Kewirausahaan Kiat dan Proses Menuju Sukses. Penerbit Salemba Empat.

Widoyoko, S. E. P. (2009). Evaluasi Program Pembelajaran. Pustaka Pelajar. 